\title{
Testing Antioxidant And Antibacterial Activity Of Andaliman Fruit (Zanthoxylum Acanthopodium Dc.) Ethanol Extract With Abts Method (2,2'-Azino-Bis(3-Ethylbenz-Thiazoline-6-Sulfonic- Acid) And Minimum Resistant Concentration
}

\author{
Agung Adha Witasa Dewana ${ }^{1}$, Tan Suyono ${ }^{2 *}$, Linda Chiuman ${ }^{3}$, Sahna Ferdinand Ginting ${ }^{4}$ \\ 1,2,3,4 Program Study Master Of Biomedic Science Faculty Of Medicine \\ Universitas Prima Indonesia Medan, North Sumatera, Indonesia \\ * Corresponding author: \\ Email: tansuyono@unprimdn.ac.id
}

\begin{abstract}
Antioxidants are chemical compounds that can donate one or more electrons to free radicals, so that these free radicals can be quenched. There are two sources of antioxidants, namely natural and synthetic antioxidants. Andaliman (Zanthoxylum acanthopodium DC.) is one of the many spice plants found in Toba Samosir and North Tapanuli Regencies, North Sumatra. Andaliman plants grow at an altitude of $1,500 \mathrm{~m}$ above sea level. Apart from North Sumatra. This research using method experimental research when collecting and processing andaliman fruit, making simplicia, making ethanol extracts and examining antioxidant activity tests using the ABTS free radical scavenging method (2,2'-azino-bis(3-ethylbenz-thiazoline-6-sulfonic acid) and antibacterial activity. using the minimum inhibitory concentration method. Testing the antioxidant activity of the ethanol extract of andaliman fruit with the ABTS method using a UV-VIS spectrophotometer with a wavelength of 734 $\mathrm{nm}$. the regression equation $(y=0.4619+20.226)$ obtained an IC50 value of $64.4598 \mathrm{mg} / \mathrm{mL}$ which can be classified as a strong antioxidant activity. The results of the antibacterial activity test of the ethanol extract of the andaliman fruit showed that the extract had antibacterial activity in the moderate category at a concentration of $300 \mathrm{mg} / \mathrm{ml}$ with an inhibition zone of 10 .
\end{abstract}

Keywords: Andaliman fruit, antioxidants, ABTS, Escherichia coli and Pseudomonas aeruginosa

\section{INTRODUCTION}

The use of natural materials as traditional medicines has recently increased greatly in Indonesia, even some natural materials have been produced on a large scale. The use of traditional medicines is considered to have fewer side effects compared to medicines derived from chemicals. Traditionally, the raw materials are easy to obtain and the price is relatively cheap (Nugraheni, 2007).Today the use of antioxidant compounds is growing, both for food and medicine. The use of antioxidants as drugs continues to be developed along with increasing knowledge about the activity of free radicals that can cause cell damage and underlie various pathological conditions (Mangela et al., 2016). Antioxidants are compounds that can play a role in preventing, inhibiting or delaying the occurrence of oxidation. Antioxidants have the ability to donate electrons that can bind and end free radical chain reactions that are deadly and can cause various diseases (Winarsi, 2007).One of the efforts to overcome resistance to antibiotics is to develop new antibacterials from plant materials. Research was conducted to find new drugs that are more effective against diseases caused by bacteria, fungi and viruses (Agromedia Editor, 2008). Various research and developments that utilize technological advances are also carried out as an effort to improve product quality and safety which are expected to further increase trust in these traditional medicines (InfoPOM, 2005).Antibacterial is a natural or synthetic compound that has the effect of suppressing or inhibiting bacterial growth. Bacteria can enter, multiply and cause infectious diseases.

One of the parts of the body that is most often infected by bacteria is the digestive tract. Cholera, diarrhea and gastroenteritis are digestive tract infections that are quite common in the wider community due to bacterial contamination of food and lack of sanitation (Anorital and Andayasari, 2011).Andaliman (Zanthoxylum acanthopodium DC.) is one of the many spice plants found in Toba Samosir and North Tapanuli Regencies, North Sumatra. Andaliman plants grow at an altitude of 1,500 m above sea level. In addition to North Sumatra, andaliman which is included in the family Rutaceae (family of oranges) is also found in India and China. The shape of the andaliman fruit is similar to a small round pepper (pepper), green 
in color, but if it is dry it is a bit blackish, when you bite the andaliman fruit you will smell a fragrant essential oil with a distinctive (bitter) taste (Wijaya, 1999). Traditionally, andaliman fruit is used as a cooking spice, besides the skin, roots and leaves are traditionally used as medicine to cure stomachache, toothache, cough, rheumatism and backache.Andaliman contains flavonoid compounds that have antioxidant activity which is very beneficial for health and plays an important role in maintaining the quality of food products from various damages such as rancidity, changes in nutritional value and changes in food color and aroma. In addition, the flavonoid compounds in andaliman can also be used as antimicrobials.

This provides an opportunity for andaliman as a raw material for antioxidant and antimicrobial compounds for the food and pharmaceutical industries (Wijaya, 1999). The results of Siswadi's study (2002), showed that andaliman fruit extract was bactericidal against the bacteria Bacillus stearothermophilus, Pseudomonas aeruginosa and Vibrio cholera, Knowing the antimicrobial activity of andaliman and its active components will increase the use of andaliman as a medicinal ingredient (Butar Butar, 2002). Another benefit of andaliman fruit based on research is as an insecticide to inhibit the growth of the insect Sitophilus zeamais, the effect is to reduce the appetite of insects (Andayanie, 2000).Based on the description above and some related literature, the researchers are interested in conducting research on antioxidant activity using the DPPH method and antibacterial using the Minimum Inhibitory Concentration (MIC) method from Andaliman fruit (Zanthoxylum acanthopodium DC.).Based on the description of the background above, the formulation of the problem in this study is how the antioxidant activity with the ABTS method (2,2'-azinobis(3-ethylbenz-thiazoline-6-sulfonic acid) and antibacterial using the Minimum Inhibitory Concentration (MIC) method. against Escherichia coli and Pseudomonas aeruginosa bacteria on andaliman fruit (Zanthoxylum acanthopodium DC.)

\section{LITERATURE REVIEW}

\subsection{Plant Description}

One of the typical spice plants found in North Sumatra is andaliman which is found growing wild in the Tapanuli area at 1500 meters above sea level at a temperature of $15-18 \mathrm{oC}$, this plant is spread among others in northern India, Nepal, East Pakistan, Myanmar, Thailand. and China (Kristanty and Suriawati, 2015).

Andaliman plant systematics (Kristanty and Suriawati, 2015):

Kingdom : Plantae

Division: Spermatophyta

Subdivision : Angiosperms

Class : Dicotyledoneae

Nation: Sapindales

Tribe: Rutaceae

Clan: Zanthoxylum

Species : Zanthoxylum acanthopodium DC.

Andaliman is one of the species of the citrus tribe (Rutaceae) known by the local names andaliman (Toba), tuba (Simalungun and Dairi) and sinyarnyar (South Tapanuli) (Kristanty and Suriawati, 2015). Andaliman's foreign names are yan-jiao (Chinese), mouh laaht faa jiu (Cantonese Chinese), mao la hua jiao (Mandarin Chinese), Indonesian lemon pepper (English), indonesischer zitronenpfeffer (Germany), tambhul (India), sansho (Japan). ) and emmay/yerma (Tibet) (Anonymous, 2012).

Andaliman is an upright shrub with a height of 3-8 m, stems and branches are reddish, grooved, downy and thorny. Andaliman fruit is small round in shape, the pericarp is dark green to reddish and the color of the seeds is black, when bitten gives off a fragrant aroma, and has a sharp and distinctive bitter taste, and can stimulate saliva production. The fruit includes true fruit with a diameter of 3-4 mm consisting of one flower with many ovules, each of which is free and then grows into a fruit but gathers on one stalk. The length of the flower is $3 \mathrm{~mm}$. The leaves are compound leaves with a length of 2-25 cm, 1-6 pairs of leaflets with short stalks, serrated leaf edges, pointed leaf tips, green leaf color and the upper surface of the leaf is older than the lower surface of the leaf. The taproot system where the institutional roots grow continues to 
become the main root which branches into smaller roots and is slightly hairy all over the surface. This plant reproduces using seeds (Siregar, 2003; Wijaya, 1999).

\subsection{Extraction.}

Taking active ingredients from a plant can be done by extraction. In this extraction process, the active ingredient will be dissolved by a solvent that matches its polarity. In the extraction process there is a mass transfer of the active substance which was originally in the cell, pulled by the solvent so that the active substance dissolves in the solvent, generally the extraction will be better if the surface of the simplicia powder in contact with the solvent is wider (Ansel, 2005). Extraction is the activity of withdrawing soluble chemical substances so that they are separated from insoluble materials with liquid solvents. The active compounds contained in simplicia can be classified into essential oils, flavonoids, alkaloids and others. Soft simplicia such as rhizomes and leaves, easily penetrated by solvents, Therefore, the extraction process does not need to be powdered until smooth. Hard simplicia such as seeds, bark and root bark are difficult to penetrate by solvents, therefore they need to be powdered until smooth (Directorate General of POM RI, 2000).

The initial process of making the extract is the stage of making dry simplicia powder (pollination) which is made with certain equipment to a certain degree of fineness. This process can affect the quality of the extract on the basis of several things, namely the finer the simplicia powder, the more effective and efficient the extraction process, but the finer the powder, the more technologically complex the equipment for the filtration stage and during the use of pollination equipment is where there is movement and interaction with hard objects. (such as metal), then heat will arise which can affect the compound content. In the extraction process, solvents are also used which need to be considered in their selection, such as selectivity, solubility, toxicity, evaporation, economy, environmental friendliness and safety (Directorate General of POM RI, 2000).

\subsection{Extraction}

Taking active ingredients from a plant can be done by extraction. In this extraction process, the active ingredient will be dissolved by a solvent that matches its polarity. In the extraction process there is a mass transfer of the active substance which was originally in the cell, pulled by the solvent so that the active substance dissolves in the solvent, generally the extraction will be better if the surface of the simplicia powder in contact with the solvent is wider (Ansel, 2005). Extraction is the activity of withdrawing soluble chemical substances so that they are separated from insoluble materials with liquid solvents. The active compounds contained in simplicia can be classified into essential oils, flavonoids, alkaloids and others. Soft simplicia such as rhizomes and leaves, easily penetrated by solvents, Therefore, the extraction process does not need to be powdered until smooth. Hard simplicia such as seeds, bark and root bark are difficult to penetrate by solvents, therefore they need to be powdered until smooth (Directorate General of POM RI, 2000).

The initial process of making the extract is the stage of making dry simplicia powder (pollination) which is made with certain equipment to a certain degree of fineness. This process can affect the quality of the extract on the basis of several things, namely the finer the simplicia powder, the more effective and efficient the extraction process, but the finer the powder, the more technologically complex the equipment for the filtration stage and during the use of pollination equipment is where there is movement and interaction with hard objects. (such as metal), then heat will arise which can affect the compound content. In the extraction process, solvents are also used which need to be considered in their selection, such as selectivity, solubility, toxicity, evaporation, economy, environmental friendliness and safety (Directorate General of POM RI, 2000).

\subsection{Free Radicals}

Free radicals are molecules or atoms that have one or more unpaired electrons in their outer orbital and can cause damage to biomolecules (Halliwel and Gutteridge, 1989). This causes free radicals to be highly reactive and able to take electrons from other molecules, such as proteins and Deoxyribose Nucleic Acid (DNA) (Hafidz, 2003). Free radicals can cause oxidative damage to biological tissues, this damage can cause chronic diseases, such as ischemia, cataracts, cancer, diabetes mellitus, aging, and coronary heart disease 
(Hiriguchi et al., 1995).Free radicals are formed in two ways, namely endogenously and exogenously. Endogenously, free radicals are generated through biochemical reactions in the body, for example enzymatic oxidation, phagocytosis, electron transport, and ischemic transition metal oxidation. Exogenously, free radicals are generated from the surrounding environment, such as air pollution, food additives, and ultraviolet (UV) radiation. These exogenous radicals will then enter the body through breathing, digestion, and skin absorption (Amelia, 2006).

Free radicals are produced endogenously in cells by mitochondria, plasma membranes, lysosomes, peroxisomes, endoplasmic reticulum, and cell nuclei (Langseth, 1995). Free radicals are generated in the body, usually consisting of reactive oxygen species (ROS) and reactive nitrogen species (RNS). Examples of derivatives of the two species include superoxide radicals $(\mathrm{O} 2 *)$, hydroxyl $\left(\mathrm{OH}^{*}\right)$, peroxyl (ROO*), hydrogen peroxide (H2O2-), singlet oxygen (1O2), nitric oxide $\left(\mathrm{NO}^{*}\right)$, peroxy nitrite (ONOO). - ), and hypochlorous acid ( $\mathrm{HOCl}$ ) (Murray et al., 2003).Atoms or molecules with these free electrons, can be used to generate energy and several physiological functions such as the ability to kill viruses and bacteria. In general, the reaction mechanism for the formation of free radicals consists of three stages, namely initiation, propagation, and termination. The initiation stage is the initial stage of the formation of free radicals. The second stage is propagation, namely the change of a free radical molecule into another form of radical (formation of new free radicals).

\section{METHODS}

The method used in this research is experimental research. The research includes collecting and processing andaliman fruit, making simplicia, making ethanol extracts and examining antioxidant activity tests using the ABTS free radical scavenging method (2,2'-azino-bis(3-ethylbenz-thiazoline-6-sulfonic acid) and antibacterial activity. using the minimum inhibitory concentration method. Colonies of Escherichia coli and Pseudomonas aeruginosa bacteria were taken from the culture stock with a sterile ose needle, then suspended in a test tube containing $10 \mathrm{ml}$ of nutrient broth (NB) solution, incubated until the same turbidity was obtained with the Mc.Farland standard solution no.0.5, means the concentration of bacteria is 108 $\mathrm{CFU} / \mathrm{ml}$.

Bacterial suspension was diluted by pipetting $0.1 \mathrm{ml}$ of bacterial inoculum into a test tube containing $9.9 \mathrm{ml}$ of nutrient broth (NB) and vortexed until homogeneous, so the concentration of bacterial suspension was equal to $106 \mathrm{CFU} / \mathrm{ml}$ (Difco and BBL Manual). , 2009).A total of $0.1 \mathrm{ml}$ of inoculum was put in a sterile petri dish, then $15 \mathrm{ml}$ of nutrient agar was poured at a temperature of $40 \mathrm{o}-50 \mathrm{oC}$. The petri dish was shaken on the table surface so that the media and bacterial suspension were evenly mixed and allowed to solidify. Antibacterial activity was tested by agar diffusion method using paper discs. Place a paper disc that has been dripped with $0.1 \mathrm{ml}$ with several concentrations of the titanus leaf fraction test solution on solid media that has been inoculated with bacteria and left for 15 minutes, then incubated in an incubator at a temperature of $36 \pm 1 \mathrm{oC}$ for 18 hours, after which the diameter of the inhibition area is measured ( clear zone) growth around the disc using a caliper.

\section{ANALYZE AND RESULT}

\subsection{Plant Identification}

The results of the identification carried out at the Herbarium Medanense (MEDA) University of North Sumatra on plant samples used in this study were leaves. Identification results showed that the sample was Andaliman fruit (Zanthoxylum acanthopodium DC.). Phytochemical screening test was carried out with the aim of identifying and identifying the components of bioactive compounds contained in the andaliman fruit extract. The components of the active compounds identified include: alkaloids, steroids/triterpenes, saponins, tannins, flavonoids and glycosides. The results of screening of andaliman fruit extracts extracted using ethylacetate solvent can be seen in Table 1 
Table 1. Phytochemical Screening Test Results Andaliman Fruit Extract

\begin{tabular}{l|l}
\hline Bioactive Compound & Andaliman Fruit Extract \\
\hline Alkoloid & + \\
Flavonoids & + \\
Saponins & + \\
Tannins & + \\
Steroids/Triterpenoids & - \\
Glycoside & + \\
\hline
\end{tabular}

\section{Description:}

\section{$(+)=$ contains compounds}

\section{$(-)=$ does not contain compounds}

Based on the results of the qualitative analysis of the active components of the andaliman extract extracted with ethylacetate solvent above, it shows that the andaliman fruit extract with ethylacetate solvent contains almost all secondary metabolites, except steroids/triterpenoids. Secondary metabolite compounds found in andaliman extract that act as antimicrobials are alkaloids, flavonoids, glycosides, saponins and tannins. Previous studies regarding the extraction of andaliman (Parhusip, 2016), there are 3 types of solvents used; hexane, methanol, ethylacetate.According to Robinson (1995), alkaloids have the ability as antibacterial and pharmacological effects as analgesics and anesthetics.

The mechanism of inhibition of bacteria by this compound is thought to be by interfering with the peptidoglycan constituent components in bacterial cells so that the cell wall layer is not fully formed and causes the death of the cell. According to Safitri (2010), saponins have potential as antimicrobial compounds because of their ability to reduce the permeability of bacterial cell walls so that they can enter the bacterial cytosol and inhibit their growth.Other metabolites found in andaliman extract are tannins. According to research Karlina et al. (2013), tannins are phenolic compounds that cause damage to cell wall polypeptides, the mechanism for inhibiting tannins occurs by lysing bacterial walls due to saponins and flavonoids, causing tannin compounds to easily enter bacterial cells and coagulate bacterial cell protoplasm. In addition, according to Robinson (1995), the mechanism of action of tannins as antibacterial is to inhibit the enzyme reverse transcriptase and DNA topoisomerase so that bacterial cells cannot be formed.

\subsection{Andaliman Fruit Ethanol Extract Antioxidant Activity Test Results}

Testing the antioxidant activity of the ethanol extract of andaliman fruit with the ABTS method using a UV-VIS spectrophotometer with a wavelength of $734 \mathrm{~nm}$. The following are the results of the antioxidant activity test, which can be seen in Table 4.1 below:

Table 2. Andaliman Fruit Ethanol Extract Measurement Results

\begin{tabular}{|l|l|l|l|}
\hline No & Concentration $(\mathrm{ppm})$ & Absorbance & \% Damping \\
\hline 1. & Blank & 1,507 & 0 \\
\hline 2. & $100 \mathrm{mg} / \mathrm{mL}$ & 0.553 & 63.2825 \\
\hline 3. & $50 \mathrm{mg} / \mathrm{mL}$ & 0.754 & 49.9447 \\
\hline 4. & $25 \mathrm{mg} / \mathrm{mL}$ & 0.997 & 33.8201 \\
\hline 5. & $12.5 \mathrm{mg} / \mathrm{mL}$ & 1,199 & 20.4601 \\
\hline
\end{tabular}

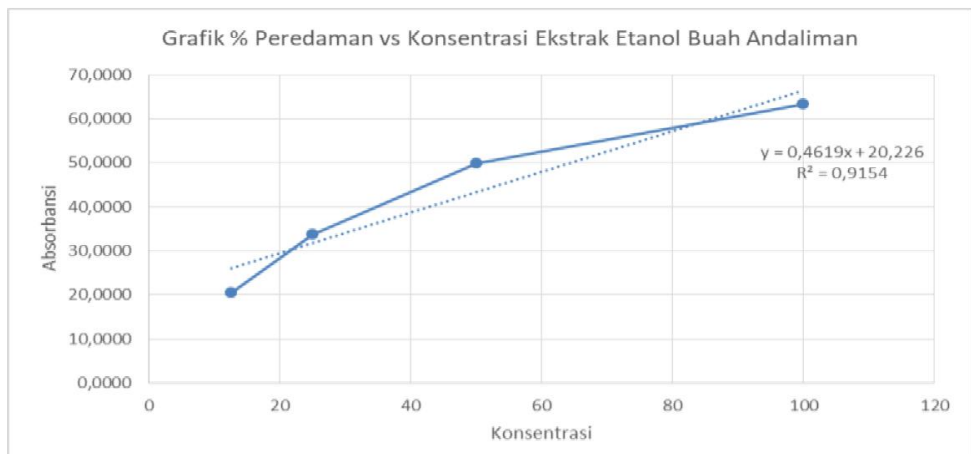

Fig 1. Graph of \% Attenuation vs Concentration of Andaliman Fruit Ethanol Extract 


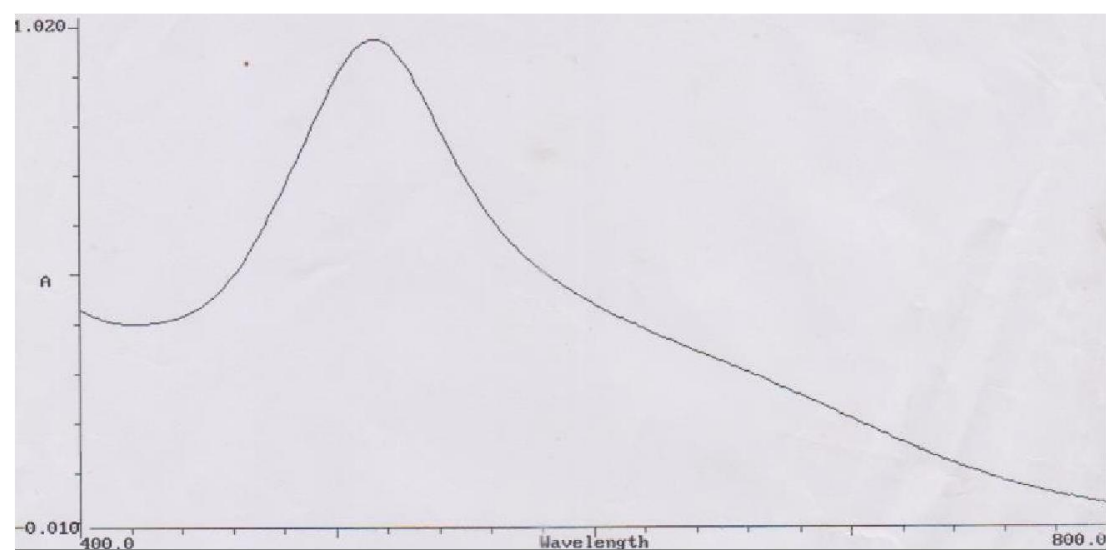

Fig 2. Maximum Wavelength Graph $734 \mathrm{~nm}$

Based on Table 1 and Figures 2 of the regression equation $(y=0.4619+20.226)$, the IC50 value of $64.4598 \mathrm{mg} / \mathrm{mL}$ can be classified as a strong antioxidant activity. The level of strength of antioxidant compounds using the ABTS method can be classified in table 4.2. The IC50 value was obtained based on the linear regression equation obtained by plotting the concentration of the test solution ( $\mathrm{ppm}$ ) as the $\mathrm{X}$-axis and the percent reduction value as the $\mathrm{Y}$-axis which was used for the antioxidant activity parameters.ABTS method is a method of determining antioxidant activity obtained from the oxidation of potassium persulfate with ABTS diammonium salt. The presence of antioxidant activity in the sample is indicated by the loss of the blue color in the ABTS reagent (Molyneux, 2004). The amount of antioxidant activity is indicated by the IC50 value. The IC50 value indicates the concentration value of the sample solution required to reduce $50 \%$ ABTS free radical activity. Based on Figure 1, it can be seen that the greater the sample concentration, the smaller the absorbance value (the higher the antioxidant activity). This is indicated by the increasing value of $\%$ inhibition.

Table 3. The Strength Level of Antioxidant Compounds Using the ABTS Method

\begin{tabular}{|l|l|}
\hline Intensity & IC50 value $(\mathbf{m g} / \mathbf{m L})$ \\
\hline Very strong & $<50$ \\
\hline Strong & $50-100$ \\
\hline Currently & $101-150$ \\
\hline Weak & $>150$ \\
\hline
\end{tabular}

\subsection{Results Andaliman Fruit Ethanol Extract Antibacterial Activity Test}

Antibacterial activity test of andaliman fruit ethanol extract was carried out against Escherichia coli and Pseudomonas aeruginosa bacteria by agar diffusion method. This can be seen from the results of the measurement of the diameter of the inhibition zone formed, which is a clear area around the paper disc. The following are the results of antibacterial activity tests with various concentrations which can be seen in the image below:

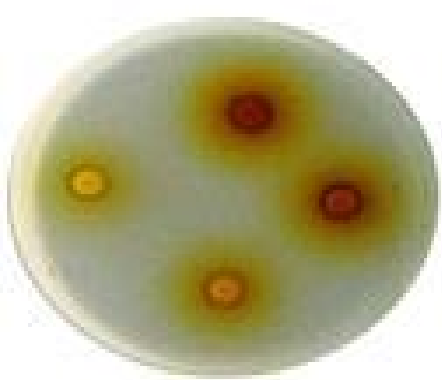

P1

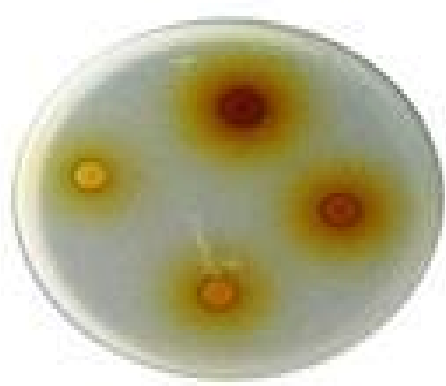

$\mathrm{P} 2$

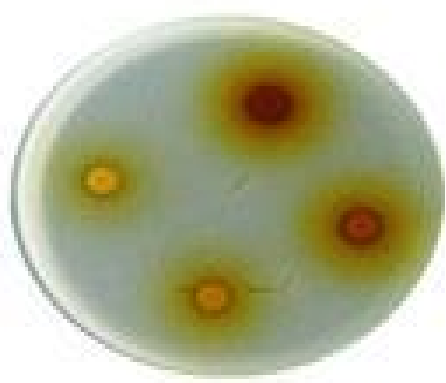

P3

Fig 3. Inhibition Zone of Escherichia coli Bacteria Methanol Extract 


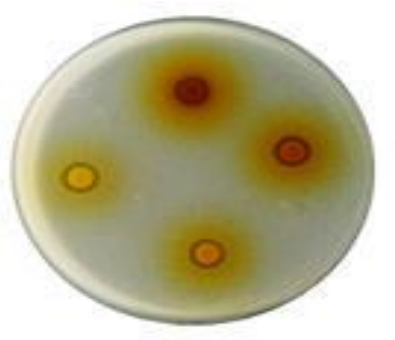

P1

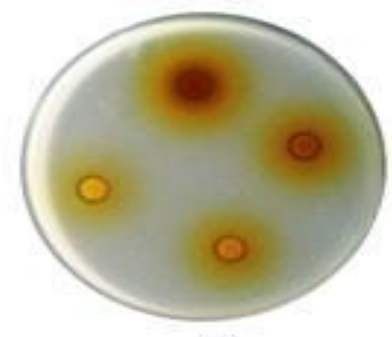

P2

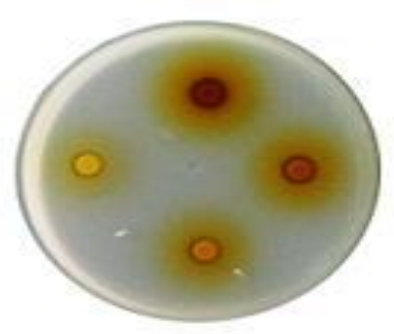

P3

Fig 4. Inhibition Zone of Pseudomonas aeruginosa Bacteria Methanol Extract

The results of the measurement of the diameter of the clear zone of antibacterial activity of andaliman fruit methanol extract against Escherichia coli and Pseudomonas aeruginosa bacteria can be seen in tables 4.3 and 4.4 below:

Table 3. Test Results of Antibacterial Activity Ethanol Extract of Andaliman

Fruit Escherichia coli bacteria

\begin{tabular}{|l|l|l|l|l|l|}
\hline Concentration $(\mathrm{mg} / \mathrm{mL})$ & P1 & P2 & P3 & X & SEM \\
\hline 300 & 10.9 & 10.6 & 11.1 & 10.87 & 0.25 \\
\hline 200 & 10.1 & 10.2 & 10.1 & 10,13 & 0.12 \\
\hline 100 & 9.2 & 9.1 & 9.2 & 9.21 & 0.26 \\
\hline 50 & 8.2 & 8.1 & 8.2 & 8.16 & 0.11 \\
\hline 25 & 6 & 6 & 6 & 6.00 & 0.00 \\
\hline 12.5 & 6 & 6 & 6 & 6.00 & 0.00 \\
\hline 6.25 & 6 & 6 & 6 & 6.00 & 0.00 \\
\hline K- & 6 & 6 & 6 & 6.00 & 0.00 \\
\hline
\end{tabular}

Table 4. Results of Antibacterial Activity Test for Andaliman Fruit Ethanol Extract, Pseudomonas aeruginosa bacteria

\begin{tabular}{|l|l|l|l|l|l|}
\hline Concentration $(\mathrm{mg} / \mathrm{mL})$ & P1 & P2 & P3 & X & SEM \\
\hline 300 & 10.5 & 9.1 & 10.5 & 10.03 & 0.36 \\
\hline 200 & 9.1 & 9.7 & 9.7 & 9.50 & 0.35 \\
\hline 100 & 7.8 & 8.2 & 8 & 8.00 & 0.20 \\
\hline 50 & 7.5 & 7.8 & 7.7 & 7.67 & 0.15 \\
\hline 25 & 7 & 6.9 & 7.1 & 7.00 & 0.10 \\
\hline 12.5 & 6.5 & 6.3 & 6.4 & 6.40 & 0.10 \\
\hline 6.25 & 6 & 6 & 6 & 6.00 & 0.00 \\
\hline K- & 6 & 6 & 6 & 6.00 & 0.00 \\
\hline
\end{tabular}

Based on Tables 4.3 and 4.4 in this study, pathogenic bacteria were used, namely Escherichia coli and Pseudomonas aeruginosa. The results of the antibacterial activity test of the ethanolic extract of andaliman fruit showed that the extract had antibacterial activity in the moderate category at a concentration of $300 \mathrm{mg} / \mathrm{ml}$ with an inhibition zone of $10.87 \mathrm{~mm}$ for Escherichia coli bacteria and a moderate category for Pseudomonas aeruginosa bacteria with an inhibition zone of $10.03 \mathrm{~mm}$. The difference in the diameter of the inhibition zone on the two bacteria indicated that there was a difference in the sensitivity of the extract to the tested microbes. Antimicrobial compounds can cause damage to cell walls and damage to cell membranes in the form of denaturation of proteins and fats that make up cell membranes.Based on the table obtained Pathogenic bacterial strains were used for antibacterial screening of andaliman fruit ethanol extract from the maceration extraction process, namely:Escherichia coli and Pseudomonas aeruginosa. inhibits bacterial growth. growth and number of bacteria $<10$ colonies. MIC is the minimum concentration of antimicrobial substances that can inhibit bacterial growth after 24 hours of incubation and it is not known that there are bacterial colonies that grow by observing the number of bacterial colonies that grow (Tortora et al., 2010). 
The inhibition zone diameter of $5 \mathrm{~mm}$ or less was categorized as weak, the inhibition zone diameter of $5-10 \mathrm{~mm}$ was categorized as moderate, the inhibition zone diameter of $10-20 \mathrm{~mm}$ was categorized as strong and the inhibition zone of $20 \mathrm{~mm}$ or more was categorized as very strong (Boateng and Diunase., 2015).Based on research that has been carried out, the ethanol extract of andaliman fruit is proven to have antibacterial activity by inhibiting the growth of P. aeruginosa and E. coli bacteria, it is proven by the large diameter of the inhibition zone formed on the test bacteria. The inhibition of bacterial growth may be thought to be due to the presence of nutritious compounds contained in the andaliman fruit.The inhibitory activity on the growth of the tested bacteria was thought to be due to the presence of saponins, camperol and anthocyanins in the compound. According to Samsumaharto and Sari (2011), saponins can work as antibacterial by damaging the cytoplasmic membrane and killing cells. Saponins can cause protein denaturation so that the cell membrane will be damaged and lysis (Siswandono and Soekarjo, 1995). Anthocyanin itself is a sub-type of organic compound from the flavonoid family, and is one of the phyllenol groups (Karnjanawipagul et al, 2010). According to Wrolstad (2001) anthocyanins apart from being good antioxidants can also act as antiviral and anti-microbial.

\section{CONCLUSION}

Based on the results of the research that has been done, it can be concluded that:

a. The ethanol extract sample of andaliman fruit has antioxidant activity with an IC50 value of 64.4598 $\mathrm{mg} / \mathrm{mL}$ classified as strong antioxidant activity.

b. The ethanol extract of andaliman fruit is a sample with very strong antioxidant activity because it has an IC50 value with a concentration of $12.5-50 \mu \mathrm{g} / \mathrm{mL}$ and a strong antioxidant activity with an IC50 value with a concentration of $50-100 \mathrm{~g} / \mathrm{mL}$.

c. The ethanol extract of andaliman fruit can inhibit Escherichia coli and Pseudomonas aeruginosa, effective at a concentration of $300 \mathrm{mg} / \mathrm{ml}$ with inhibitory diameters of $10.87 \mathrm{~mm}$ and $10.03 \mathrm{~mm}$, respectively.

\section{REFERENCES}

[1] Alamsyah, AN 2006. Conquer Disease with Green Tea. Jakarta: Agrimedia Pustaka Publisher. Pages: 74-95

[2] Amelia G. 2006. Potential of pearl grass (Hedyotis corimbosa Lam.) as a natural antioxidant. Essay. Bogor: Faculty of Mathematics and Natural Sciences, Bogor Agricultural University. page 40.

[3] Andayanie, L. 2000. Study of Natural Insecticide Power of Vegetables Peel of Mangosteen (Garcinia Mangostana. L), Andaliman Fruit (Zanthoxylum Acanthopodium DC.), Gambir Sap (Uncaria Gambir Roxb.) And Tea Leaves (Camellia Synthesis L.) Against Pest Development Warehouse Sitophilus Zeamais Motsch. Essay. Faculty of Agricultural Technology IPB. Bogor.

[4] Anggraini, R., Salim, M and Elida, M. 2013. Test of Antibiotic-resistant Esherichia coli bacteria in CottonCotton Fish in Batang Arau River, Padang. Journal of Chemistry Unand. 2(2) : 47-59

[5] Anorital., Andayasari, L. 2011. Epidemiological study of digestive tract infectious diseases caused by amoeba in Indonesia. Health Research and Development Media. 21(1): 1-2.

[6] Ansel, HC (2005). Introduction to Pharmaceutical Dosage Forms. Translator: Farida Ibrahim. Fourth Edition. Jakarta: University of Indonesia (UIPress) Publisher. Pages 607-609.

[7] Boateng, J. and Diunase, KN (2015). comparing the antibacterial and functional properties of cameroonian and manuka honeys for potential wound healing-have we come full cycle in dealing with antibiotic resistance. molecules, (20), 16068.

[8] Buck, DF 1991. Antioxidants. In: J. Smith, editor. Food Additive User's Handbook. Blackie Academic and Professional. Glasgow-UK.

[9] Butar-butar, B, L, S. 2002. Studying the Diffusivity of Heat in Pepper Plants (Piper nigrum L.) and Andaliman (Zanthoxylum acanthopodium DC.). Essay. Faculty of Agricultural Technology IPB. Bogor

[10] Cui XG; Zhao, QJ; Chen, QL; Xu, L.; Song, Y.; Jin, YS and Xu, DF (2008). Two New Benzophenanthridine Alkaloids from Zanthoxylum nitidum. Helvetica Chimica Acta. 91(1): 155-158.

[11] Chen, JJ; Chen, PH; Liao, CH; Huang, SY and Chen, IS (2007). New Phenylpropenoids, Bis (1-phenylethyl) phenols, Bisquinolinone Alkaloids, and Anti-inflammatory Constituents from Zanthoxylum integrifoliolum. Journal of Natural Products.70:1444-1448.

[12] Cosentino, S., Barra, A., Pisano, B., Cabizza, M., Pirisi, FM and Palmas., F. 2003. Composition and 
antimicrobial properties of Juniperus sardines essential oils against foodborne pathogens and spoilage microorganisms. J Food Prot 66(7):1288-1291.

[13] Day, RA, and Underwood, AL 1986. Quantitative Chemical Analysis. Edition IV. Translation of Sopyan, I. Jakarta: Erlangga Publisher. Case. 382.

[14] Difco Manual of Dehydrated Culture Media and Reagents for Microbiology and Clinical Laboratory Procedures. Ninth edition. Detroit Michigan: Difco Laboratories. Pages 29, 32.

[15] Directorate General of POM RI. 1979. Indonesian Pharmacopoeia. Third Edition. Jakarta: Indonesian Ministry of Health. Case. 100, 649-653, 659, 696, 733, 772.

[16] Directorate General of POM. 1995. Indonesian Pharmacopoeia. Fourth Edition. Jakarta: Ministry of Health of the Republic of Indonesia. Pages 7, 891 - 898, 1035.

[17] Directorate General of POM RI. (2000). General Standard Parameters of Medicinal Plant Extracts. Jakarta: Ministry of Health of the Republic of Indonesia. Pages 1-11.

[18] Fernandes, CC; Vieira, PC; da Silva, VC; Dall'Oglio, EL; da Silva, LE and de Sousa, PT (2009). 6-Acetonyl-Nmethyl-dihydrodecarine, a New Alkaloid from Zanthoxylum riedelianum. Journal of the Brazilian Chemical Society. 20(2): 379-382.

[19] Gandjar, IG, Rohman, A. 2007. Analytical Pharmaceutical Chemistry. Yogyakarta: Student Library. page 222.

[20] Gurav, S., Deshkar, N., Gulkari, V., Duragkar N., Patil, A.2007. Free Radical Scavenging Activity of Polygala Chinensis Linn. Pharmacologyline. 2(3): 245-253.

[21] Hafidz, AF 2003. Anti-free radical activity of DPPH methanol fraction Fagreaea auriculata and Fagreaea ceilanica. Pharmacy Magazine. Airlangga III: April 1, 2003

[22] Halliwell B., Guteridge JMC. 1986. FreeRadical in Biology and Medicine. Clarendon Press, New York: Oxford University Press. Page 384-385

[23] Harborne, JB (1996). Phytochemical Methods, A Guide to Modern Ways of Analyzing Plants. Kosasih Padmawinata Translation. Edition II. Bandung: ITB Press. Pg 147.

[24] Helrich, K. 1990. AOCS Official Methods of Analysis. First Edition. Arlington: AOAC. 956.

[25] Hernani, Rahardjo, M. 2005. Antioxidant Efficacious Plants. Jakarta: Self-Help Spreader. page 17.

[26] Hiriguchi, H., Saito, T., Okamura, N., Yagi, A. 1995. Inhibition of lipid peroxidation and superoxide generation by diterpenoids from Rasamarinus officinalis. Planta Medica 61: 333-336.

[27] Hu, U Zhang, WD; Liu, RH; Zhang, C.; Shen, YH; Li, HL; Liang, MJ and Xu, XK (2006). Benzophenanthridine alkaloids from Zanthoxylum nitidum (Roxb.) DC, and their analgesic and anti-inflammatory activities. Chem Biodivers. 3(9): 990-5.

[28] Hynniewta, SR, Kumar, Y. (2008). Herbal Remedies Among The Khasi Traditional Healers And Village Folks In Meghalaya. Indian Journal of Traditional Knowledge. 7(4): 481-586.

[29] Ionita P. (2003). Is DPPH Stable Free Radical a Good Scavenger for Oxygen Active Species. Romania.

[30] Jawetz, E., Melnick, JL, and Adelberg, EA 2001. Medical Microbiology. XXII Edition. Jakarta: Salemba Medika Publisher. Pages 205-209.

[31] Karnjanawipagul, P., W. Nittayanuntawech., P. Rojsanga., L. Suntornsuk. (2010). Analysis of -Carotene in Carrot by Spectrophotometry. Journal of Pharmaceutical Science 37 (1-2): $8-16$

[32] Kumalaningsih, S. 2006. Natural Antioxidants. Surabaya: Trubus Agrisarana. page 24.

[33] RE, and Junie, S. (2015). The Indonesian Zanthoxylum acanthopodium DC. : Chemical And Biological Values. International Journal of Pharm Tech Research, 8(6) : 313-321.

[34] Langseth L. 1995. Antioxidants and Their Effect on Health. In: Schmidl MK, P Labuza, editor. Essentials of Functional Food. Maryland: An Aspen Publication.

[35] Mardawati, E., Achyar, CS, Marta, H. 2008. Study of Antioxidant Activity of Mangosteen Peel Extract (Garcinia mangostana L) in the Context of Utilizing Mangosteen Peel Waste in Puspahiang District, Tasikmalaya Regency. Young Researcher Research Final Report (LITMUD). Bandung : Padjadjaran University. page 17.

[36] Mangela, O., Ridhay, A., Musafira. 2016. Study of Antioxidant Activity of Tembelekan Leaf Extract (Lantana camara L) Based on Solvent Polarity Level. COVALEN. 2(3): 16-23.

[37] Melliawati, R. 2009, Escherichia coli in Human Life, Journal of BioTrends 4 (4) . 10-14.

[38] Molyneux P. (2004) The use of the stable free radical diphenylpicrilhydrazyl (DPPH) for estimating antioxidant activity. Journal of science technology. 26; 211-219 